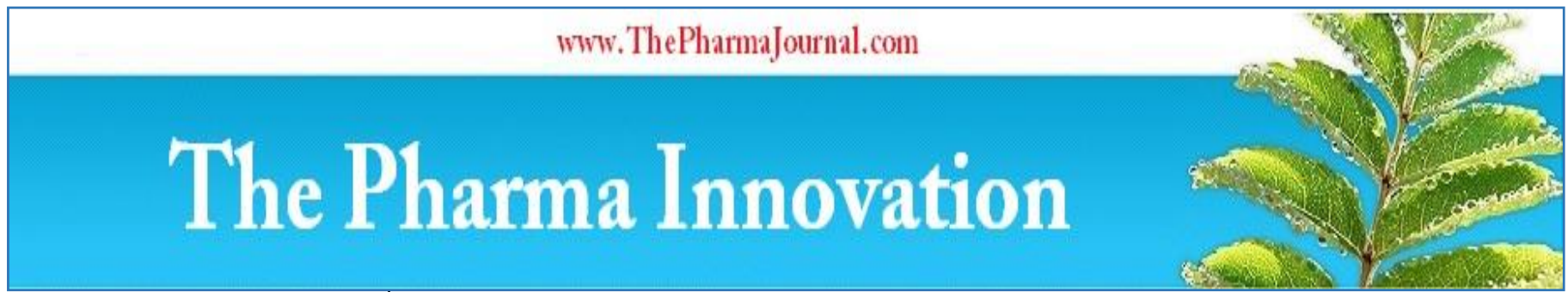

ISSN (E): 2277- 7695

ISSN (P): 2349-8242

NAAS Rating: 5.03

TPI 2020; 9(1): 138-141

(C) 2020 TPI

www.thepharmajournal.com

Received: 22-11-2019

Accepted: 26-12-2019

Suchitra Chanu Heikrujam

Department of Plant Pathology,

Pandit Deen Dayal Upadhyay

Institute of Agricultural

Sciences, Utlou, Manipur, India

RK Imotomba Singh

Department of Plant Pathology,

Pandit Deen Dayal Upadhyay

Institute of Agricultura

Sciences, Utlou, Manipur, India

Pinky Chanu Laiphrakpam

Department of Plant Pathology,

Pandit Deen Dayal Upadhyay

Institute of Agricultural

Sciences, Utlou, Manipur, India

Supriya Laishram

Department of Plant Pathology,

Pandit Deen Dayal Upadhyay

Institute of Agricultural

Sciences, Utlou, Manipur, India

Corresponding Author:

Suchitra Chanu Heikrujam

Department of Plant Pathology,

Pandit Deen Dayal Upadhyay

Institute of Agricultural

Sciences, Utlou, Manipur, India

\section{Isolation and characterization of Ralstonia solanacearum from infected tomato plants of Bishnupur district of Manipur}

\section{Suchitra Chanu Heikrujam, RK Imotomba Singh, Pinky Chanu Laiphrakpam and Supriya Laishram}

DOI: https://doi.org/10.22271/tpi.2020.v9.i2c.4363

\section{Abstract}

The bacterial wilt of tomato, caused by Ralstonia solanacearum is a major disease of the crop in areas under bacterium is well established and soil conditions are favourable for it. The pathogen can be disseminated into a clean field through contaminated water sources, symptomless yet contaminated seedlings, as well as humans or machinery carrying infested soils as it is soil borne disease. The present investigation were done at tomatoes growing areas of Bishnupur District namely Kumbi, Kwakta, Kwaksiphai, Irengbam Awang Leikai, Toubul, Khoijuman, Kabaw-Watching. Symptoms consists of wilting of the youngest leaves at the ends of the branches during the hottest part of the day. Isolation of infected plants were done from 5 disease plants found among the collected plants from different parts of Bishnupur District. Isolations were done on SPA media. They were found positive for gram staining, $\mathrm{KOH}$ test. Finally, isolates were identified as bacterial wilt disease causing pathogen i.e., Ralstonia solanacearum

Keywords: Bacterial wilt, Ralstonia solanacearum, hypersensitivity, Pathogenecity, gram staining

\section{Introduction}

At the very first stage of stages of disease, the first symptoms of bacterial wilt of tomato are seen on the foliage of plants. These symptoms consist of wilting of youngest leaves at the ends of the branches during the hottest part of the day. (Plate 1). Plants may recover at night, when the temperature cools down. The entire plant wilt quicky and leads to wilting and yellowing of foliage and finally plant died under favourable conditions. In young stem of tomato, those infected vascular bundles may become visible as long, narrow, dark brown, streaks. The youngest leaves of tomato are the first to be affected and have a flaccid appearance, usually at the warmest time of day (Vanitha et al., 2009) ${ }^{[1]}$

A sign of bacterial wilt of tomato seen at the surface of freshly cut portion from infected stems is a sticky, milky- white exudates, which shows the presence of dense masses of bacterial cells in infected vascular bundles, mostly in xylem.

Another important sign of this disease was observed when the cut stem portions are placed in clear water. It contain viscous white spontaneous slime streaming from the cut end of the stem. This sreaming represents the bacterial ooze exuding from the cut ends of colonized vascular bundles Plate 2.

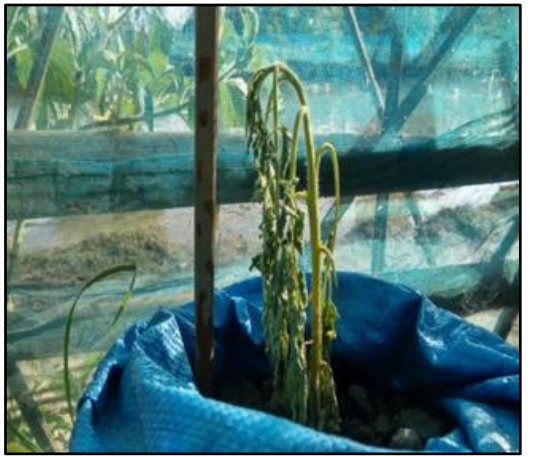

Plate 1: Symtoms of Bacterial wilt disease of tomato $\sim 138 \sim$ 


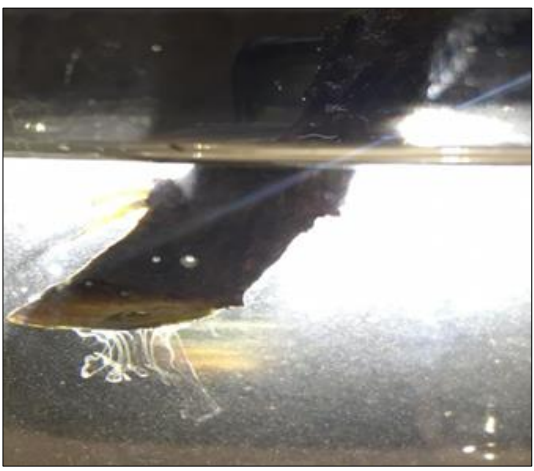

Plate 2: Bacterial ooze test

\section{Materials and Methods}

\section{Collection from different locations of Bishnupur district}

Several survey were conducted to collect the diseased samples of bacterial wilt of tomato from tomato growing areas of Bishnupur district of Manipur. The survey of tomato were conducted during June to July in different locations of tomato growing areas of Bishnupur district namely, Irengbam, Khoijuman, Toubul, Kumbi, Kwakta, Kwasiphai. Incidence of bacterial wilt of each site were calculated.

Incidence $(\%)=$ number of wilted plants/total number of plants X 100

Table 1: Disease scale developed by Winstead and Kelman (1952) ${ }^{[2]}$ was used to record the degree of resistance against bacterial wilt

\begin{tabular}{|c|c|c|}
\hline Disease scale & Expanded value & Disease incidence \\
\hline 0 & Highly resistant (HR) & $0 \%$ \\
\hline 1 & Resistant (R) & $1-20 \%$ \\
\hline 2 & Moderately Resistant (MR) & $21-40 \%$ \\
\hline 3 & Moderately susceptible (MS) & $41-60 \%$ \\
\hline 4 & Susceptible (S) & $61-80 \%$ \\
\hline 5 & Highly susceptible (HS) & $>80 \%$ \\
\hline
\end{tabular}

\section{Glasswares sterilization}

The glasswares that were used at the time of study like petridishes, conical flasks, beakers, test tubes etc were properly cleaned with detergent washed it in running tap water. Then the glasswares were sterilized by autoclaving at $15 \mathrm{lb}$ pressure and at $121{ }^{\circ} \mathrm{C}$ for 20 minutes.

Table 2: Media used during the study

\begin{tabular}{|c|c|}
\hline Media \& its ingredients & Quantity (g/l) \\
\hline SPA & \\
\hline Sucrose & 20 \\
\hline Peptone & 5 \\
\hline $\mathrm{K}_{2} \mathrm{HPO}_{4}$ & 0.5 \\
\hline $\mathrm{MgSO}_{4} 7 \mathrm{H}_{2} \mathrm{O}$ & 0.25 \\
\hline Agar & 15 \\
\hline Water (distilled) 1 litre & \\
\hline $\mathrm{Ph} 7.2-7.4$ & \\
\hline &
\end{tabular}

Isolation of bacterial wilt pathogen from effected parts of the collected samples near stem of freshly wilted plant with vascular discoloration

\section{Selection from infected parts near roots}

The collected tomato plants which shows wilting symptoms were properly washed through running tap water. The fresh stem of bacterial wilt showing symptoms plants with vascular discoloration was cut using a sharp knife in pieces. The pieces is sterilizes in $70 \%$ ethyl alcohol and subsequent rinsed in sterile distilled water for about 4 times.

\section{Bacterial ooze test}

The surface sterilized diseased plant part was cut into tiny pieces with a pre sterilized scissor and then placed in $5 \mathrm{ml}$ of sterile water taken in culture tube and keep for about 30minutes and allow the bacteria in these tissues to ooze out during which the water turned turbit. The bacterial ooze was used for bacterium isolation.

\section{Preparation of inoculum for isolation}

After confirmation of presence of bacterial ooze, the effected parts was cut into tiny pieces from the specimen by using sterile sharp blade and suspended in $3 \mathrm{ml}$ of sterile water in test tube. And the tiny pieces were allowed to diffuse bacterium at room temperature for at least 30 minutes

\section{Streaking on PSA plates}

A loopful of the bacterial suspension was taken with sterile wire loop and streaked on pre sterilized moisture free PSA plates.

\section{Incubation}

The streaked plates were then incubated in an upside down position at 24 to 48 hours in BOD maintained at $28 \pm 1{ }^{0} \mathrm{C}$. Daily observation was made after streaked plate in incubated. Saprophytic bacteria mostly appeared after 24 hours.

\section{Purification and maintenance of bacterial wilt pathogen}

A single isolated bacterial colony from PSA plates which show characteristic features of Ralstonia were picked up, restreaked on new pre sterilizes PSA plates to obtain pure culture and some are transferred on PSA slants and incubate at $30^{ \pm 2}{ }^{0} \mathrm{C}$ for 24 to 48 hours. PSA medium was used at the time of isolation, purification and maintenance of bacterial wilt pathogen

\section{Bacterial suspension preparation}

Bacterial suspensions were mostly used during pathogen tests. For this, $5 \mathrm{ml}$ of distilled water was taken in on culture tube and sterilize in an autoclave for $121{ }^{\circ} \mathrm{C}$ for 20 minutes. After cooling the culture tube, loops full of 24 hours old bacterial growth were transferred aseptically into each tube. And then bacterial mass was mixed with sterilized water by gentle shaking. The concentration of bacteria was adjusted to $10^{6}$ $\mathrm{Cfu} / \mathrm{ml}$ using previously standardized spectrophotometer which read its turbidity as $\mathrm{O} . \mathrm{D}=0.17$ at $520 \mathrm{~nm}$.

\section{Pathogenecity test}

For this test, collected samples of healthy seedlings were used. The test was done under pot culture conditions in plant pathology department. The suspension was adjusted to get at $10^{6} \mathrm{CFU} / \mathrm{ml}$ with the help of spectrophotometer which read its turbidity as $\mathrm{O} . \mathrm{D}=0.17$ at $520 \mathrm{~nm}$. The roots of seedlings of tomato plants were dipped in the bacterial suspension for 1015 minutes. Then the treated seedlings were planted in pots containing sterile soil. The untreated plants served as control. The treated seedlings which were planted in sterile soil were covered with perforated polythelene bags in order to maintain high humidity inside for 24 hours. Observations on bacterial wilt incidence were recorded from 24 hours after inoculation. It was confirmed by doing ooze test.

\section{Hypersensitivity in tobacco}

Hypersensitivity test was done to confirm the pathogenecity test. With a syringe and 25 gauge needle inject a fresh, very 
cloudy bacterial suspension $\left(10^{6} \mathrm{cfu} / \mathrm{ml}\right)$ into interveinal tissue of a tobacco leaf. Local variety tobacco plant was used in experiment. The plants were examined for hypersensitivity reaction 1 day after inoculation.

\section{Gram staining}

Gram staining was performed based on Skerman (1967)

Reagent

a. Crystal violet

Crystal violet $2.0 \mathrm{~g}$

Ammonium oxalate $1.0 \mathrm{~g}$

Distilled water $100 \mathrm{ml}$

b. Iodine solution

Iodine $1.0 \mathrm{~g}$

Potassium iodide $2.0 \mathrm{~g}$

Distilled water $100 \mathrm{ml}$

c. Aqueous safranin

Safranin $2.5 \%$ solution in $95 \%$ ethanol (stock solution)

With distilled water 1: 10 (working solution)

\section{Procedure of gram staining}

1. $48 \mathrm{hr}$ old culture was used for preparation of bacterial smear on grease free slides dried in air for a few minutes and heat fixed over the flame of spirit lamp.

2. Crystal violet was then applied to smear for 1 minute and washed in tap water for a few seconds and drained off excess water.

3. Iodine solution was applied to smear for 1 minute and again washed in tap water for few seconds.

4. The smear was then discolorizes for about 30 seconds with $95 \%$ ethanol dropwise until no more color ran from lower edge for 2 seconds and washed with tap water.

5. Counter stained the smear with safranin for 3 minutes and washed in tap water, dried in air, and examined under oil immersion ofjectives of microscope.

\section{KOH solubility test}

$\mathrm{KOH}$ solubility test was done to confirm whether to test isolate were pathogen or not.

\section{Reagents \\ $\mathrm{KOH} 3.0 \mathrm{~g}$ \\ Distilled water $100 \mathrm{ml}$}

\section{Procedure of KOH solubility test}

1. Take two drops of $3 \%$ potassium hydroxide $(\mathrm{KOH})$ and placed on a clean grease free slide.

2. A tiny colony of organism was picked up from surface of solid PSA medium with sterilized inoculating loop.

3. The material was stirred in the $\mathrm{KOH}$ for about 30 seconds and then the inoculating loop was raised from the drop to see the reaction.

\section{Results}

\section{Survey on different locations of Bishnupur district}

Survey was conducted to collect the diseased samples of bacterial wilt of tomato from tomato growing areas of Bishnupur district of Manipur namely, Irengbam, Khoijuman, Toubul, Kumbi, Kwakta, Kwasiphai. From each field fifty plants, each after every 5 following zigzag pattern, was randomly observed and after applying the following formula, incidence of bacterial wilt of each site was calculated.

Disease scale developed by Winstead and Kelman (1952) ${ }^{[2]}$ was used to record the degree of resistance against bacterial wilt that different samples collected from Kumbi, Kwakta, Kwaksiphai, show highly resistance to bacterial wilt pathogen in Manipur. And the samples collected from Irengbam Awang Leikai, Toubul, Khoijuman showed resistance to bacterial wilt pathogen. Whereas those samples collected from KabawWatching showed moderate resistance to the pathogen (Table $1)$.

Table 3: Details of village

\begin{tabular}{|c|c|c|c|c|c|}
\hline Name of the village & Number of the plants assessed & Number of diseased plants & disease incidence & expanded value & disease scale \\
\hline Kabaw- Wakching & 640 & 144 & $22 \%$ & moderate resistance (MR) & 2 \\
\hline Irenbam Awang Leikai & 420 & 12 & $3 \%$ & Resistant (R) & 1 \\
\hline Toubul & 240 & 31 & $12 \%$ & Resistant (R) & 1 \\
\hline Khoijuman & 1800 & 264 & $14 \%$ & Resistant (R) & 1 \\
\hline Kumbi & 96 & 0 & $0 \%$ & Highly resistant (HR) & 0 \\
\hline Kwakta & 120 & 0 & $0 \%$ & Highly resistant (HR) & 0 \\
\hline Kwaksiphai & 166 & 0 & $0 \%$ & Highly resistant (HR) & 0 \\
\hline
\end{tabular}

Isolation, morphology and identification of the pathogen Some isolates representing different locations were collected from different tomato fields in Bishnupur District. The organism was then isolated from the wilted tomato plants. The bacterium were appear as white or creamy white, circular to irregular, convex, glisterning surfaces on the medium. The morphological character of the pathogen revealed that the isolate bacterial was rod shaped, gram negative, motile by polar flagella. The organism produced whitish pin head size colonies on PSA medium after $48 \mathrm{~h}$ of incubation at the temperature $28 \pm 1{ }^{0} \mathrm{C}$. The organism were also found to be positive $\mathrm{KOH}$ solubility test. Thus the organism was confirmed as gram negative (Plate 3).

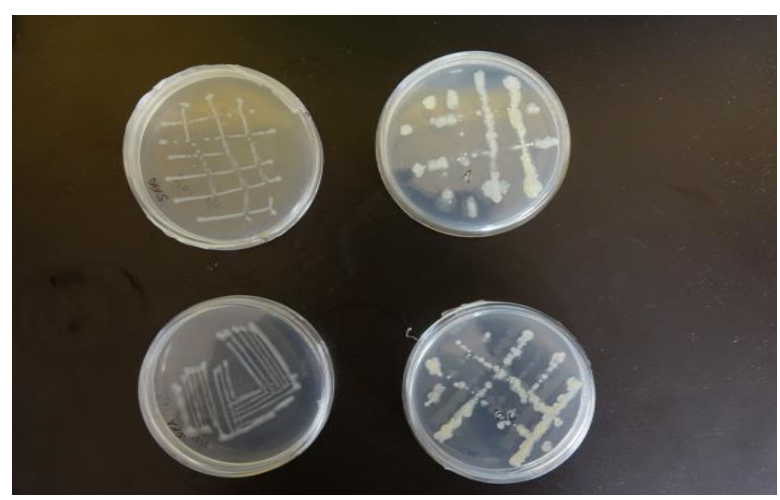

Plate 3: Ralstonia solanacearum culture 


\section{Symptoms}

At first, symptoms of this disease were seen on the foliage of plants. These symptoms consist of wilting of the youngest leaves at the ends of the branches during the hottest part of the day. At this stage, one or half a leaflet wilted and soon recovered at night when temperature cools down. Wilt disease develops under ideal environmental conditions and the entire plant wilted quickly under the favourable conditions and leads to general wilting and yellowing of foliage and caused death of plants. Another common symptoms of this deasease was stunting of plants.

\section{Pathogenecity test}

The healthy tomato seedlings were inoculated artificially with bacterial culture of inoculums containing $10^{6} \mathrm{CFU} / \mathrm{ml}$ which read $\mathrm{O} . \mathrm{D}=0.17$ at $520 \mathrm{~nm}$ by root inoculation method in which young roots were cut with sterile scissor and dipped in the inoculums for about 20 minutes and transplanted in the sterilizes soil taken in polythene bags. Observations were taken for wilting every day after 5 days of inoculation. The result of this test showed almost all of the seedlings start to wilt 7 days after inoculation.

\section{Hypersensitivity}

This bacterium also gave Hypersensitivity Reaction which was recorded. Hence, the isolated bacterium of diseased tomato plant was a pathogenic bacterium.

\section{Gram staining}

It was done to check whether the bacterial isolate was gram positive or gram negative. The gram positive show the color of crystal violet and the gram negative show the color of safranin and appear a pink to red. The bacterium retain saffranin color and it shows that the bacterium is gram negative. Under 100x objective with oil emersion, bacterium was found to be in rod shape. (Plate 4.)

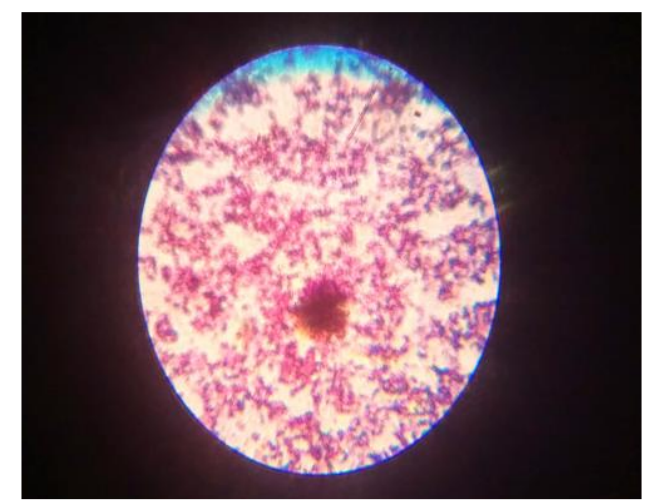

Plate 4: Result of gram staining

\section{References}

1. Vanitha SC, Niranjana SR, Umesha S. Role of Phenylalanine Ammonia Lyase and Polyphenol Oxidase in Host Resistance to Bacterial Wilt of Tomato. Journal of Phytopathology. 2009; 157:552-557.

2. Winstead NN, Kelman A. Inoculation techniques for evaluating resistance to in Pseudomonas solanacearum. Physiopathology. 1952; 42(11):628-634. 